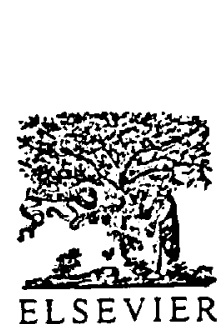

$$
\begin{aligned}
& 1 \times-29-2 R \\
& \text { C }
\end{aligned}
$$

\title{
Bioprocessing in microgravity: applications of continuous flow electrophoresis to rat anterior pituitary particles ${ }^{1}$
}

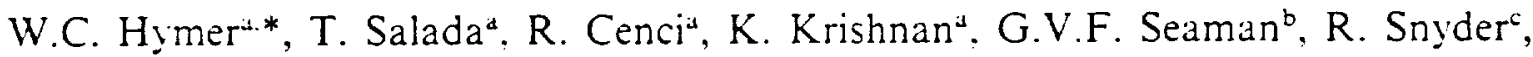 \\ H. Matsumivad. S. Nagaoka ${ }^{\mathrm{d}}$

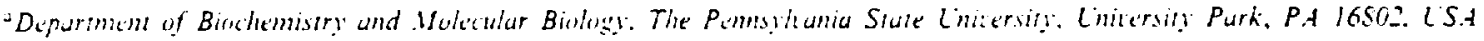

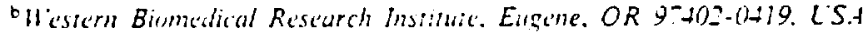

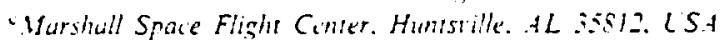 \\ ¿Biosysiems Imernational. Inc. Minaro-Kia. Tikin. 106. Jipan

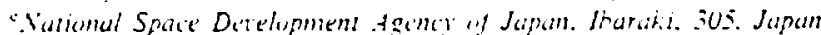

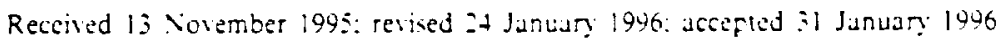

\begin{abstract}
In this repon we describe the results of a continuous how electrophoresis (CFE) experiment done on STS-65 in which we lested the idea that intracellular growth hormone $(\mathrm{GH})$ pirticles contained in a cell lysute prepured (rom cultured rat anterior pituitary cells in microgravity might have different electrophoretic mobilities from ihose in a synchronous ground control cell lysate. Collectively. the results suggested that CFE processing in miciogravity was better than on earth: more sample could be processed time $(6 \times)$ and more variant forms of GH molecules could be resolved as well. We had also hoped to carry out a pituitary cell CFE experiment. but failure of the hardware required that the actual cell electrophoresis trials be done on earth shorly after Shuttle landing. Data from these experiments showed that space-fiown cells possessed a higher elecirophoretic mobility than ground control cells. thereby offering evidence for the idea that exposure of cultured cells to microgravity can change their net surface charge-density especially when the cells are fed. Collectively. the results from this pituitary cell experiment document the advantage of using coupled cell culture and CFE techniques in the microgravity environment.
\end{abstract}

Keywords: Continuous fow electrophoresis: Microgravity

\section{Introduction}

Even though continuous flow electrophoresis (CFE) was first introduced about 35 years ago

\footnotetext{
'Presented in part at the American Society of Gravitational and Space Biology Meetings Washington, DC, 1995.

* Corsesponding author.
}

(Barrolier et al., 1958; Hannig, 1961), it is only quite recently that there has been renewed interest in this technology (Roman and Brow'n, 1994; Dalens et al., 1995). As pointed out by Roman and Brown "...the tremendous growth of biotechnology over the past decade has necessitated the - development of purification methods for isolating a single compound from a complex biological 
matrix" (Roman and Brown. 1994). The CFE process has attracted interest because it is continuous, does not use organic solients. and avoids the use of support media (e.g. gels).

A number of studies indicate that the CFE process may also be quite useful for applications requiring cell separation. In fact. a recent book summarizes its theoretical basis in addition to providing a description of results from many laboratories using this technology for the separation of diverse cell types such as subpopulations of mammalian lymphocytes and human cancer cells (Baver. 1994a).

Distortions of the sample stream occur during CFE processing: these are hydrodynamic. electrodynamic and electrohydrodynamic in character. Some are limited by gravity. Gravitational effects on biological systems relevant to electrophoretic measurements include sedimentation of cells and organelles. flotation of some lipid materials. buoyant convection. and segregation of components by density and perhaps flows which originate from the interplay of density gradients and interfacial tension. In the case of continuous flow electrophoresis there are also electrohydrodynamic effects (Rhodes et al.. 1989). It is therefore not surprising that the theoretical advantages of doing CFE processing in microgravity have been tested in spaceflight experiments dating back to 1982. This history has been reviewed by Morrison (Morrison. 1994). Perhaps the best evidence for enhanced resolution of separated cells by CFE in low gravity was obtained using fixed red blood cells from three different species during a $5 \mathrm{~min}$ suborbital rocket flight (Hannig et al., 1990).

While $g$ does not formally appear in the electrophoretic mobility equations. the applied electric field produces Joule heating with resultant fluid density differences and heat induced convective flows. While microgravity largely eliminates the convective flows, the Joule heating can only be dissipated by diffusion which is an inefficient process.

There are also a number of indirect effects of gravity which will influence the behavior of biological systems, including impairment of removal of metabolically derived heat because of absence of thermal and solutal convection and the effects of modified long-range transport and concentration oscillations (Kessler and Bier, 1977). Biologjcal cell heat for the resting metabolism of a typical nucleated cell is about a picowatt $\left(10^{-12}\right.$ Joules per s) and when active. the heat generated is about a 100-fold greater. Under the circumstances, diffusion may be insufficient as a means of removing the generated heat and a sustained rise in temperature of the cell may occur.

Our laboratory has applied electrophoresis technology to the separation of rat pituitary cells and their subcellular constituents (Plank et al.. 1983: Hayes et al.. 1990). In 1983 we attempted a CFE experiment in microgravity (Hymer et al.. 1987). Increased bandspread of the recovered cells suggested enhanced resolution of the different hormone-containing cell types. but poor recoveries and biological contamination did not establish this point definitively. The availability of Japanese cell culture kits (CCK) and the NASDA free flow electrophoresis unit (FFEL) during the 14-day IML-? mission allowed us to design a CFE trial that was coupled to pituitary cells in the CCK. This report describes those data.

\section{Materials and methods}

In its original design, two continuous flow electrophoresis (CFE) trials were to have been done in microgravity. One used a freshly prepared rat pituitary cell lysate; the other used enzymatically. dispersed rat pituitary cells. Both samples were to have been prepared for CFE processing in microgravity using the cell culture kits (CCKs) described in the companion report (Hymer et al., 1996a); however, because of technical problems with the CFE hardware, only the cell lysate CFE experiment was actually attempted in microgravity. The procedures which were followed in this trial are outlined in Fig. 1. Pituitary cells $(4 \times$ $10^{7}$ ) in each of two CCKs were prepared at L-3 days exactly as described for the cell culture portion of this experiment (Hymer et al., 1996a). Cells in these two CCKs were not fed prior to preparation of the cell lysate on mission day 9. As show'n in Fig. 1, only $\sim 50 \%$ of each ground and flight lysate was actually used for processing in 
PART 1. PITUITARY CELL LYSATE ELECTROPHORESIS STUDY

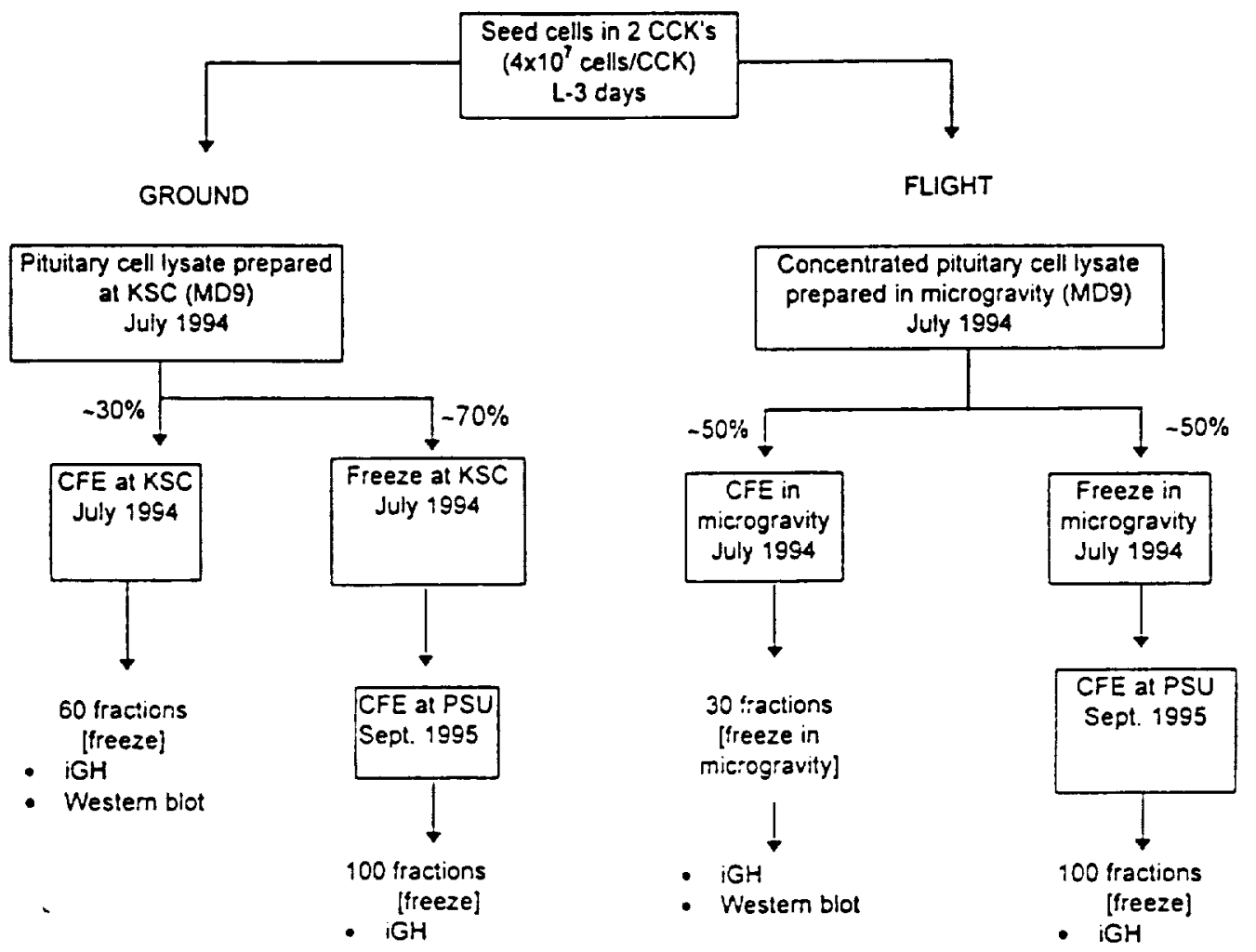

Fig. 1. Experimental design and timing of operations involing CFE of pituitary cell lysate. See Muterials and Methods for details.

the July 1994 experiment; the remainder were processed by CFE at Penn State later.

The procedures which were followed in the cell electrophoresis study are outlined in Fig. 2. After Shuttle landing, cells were removed from CCK 1 (fed $t x$ in microgravity) and from CCK 3 (not fed during the 14 days in microgravity) (Hymer et al., 1996a) using our routine trypsinization procedures (Hymer and Hatfield, 1983). Cell viabilities at this point averaged 93 and $90 \%$ for CCK 3 and CCK 1 , respectively. Sufficient cells were obtained after CFE processing of the cells from CCK 1 to do a 6 day culture with the separated cells; this was not possible for those from CCK 3 because cell numbers were insufficient.

\subsection{Cell lysis}

On mission day 9 , cell culture medium was removed and the cells in the CCK were washed briefly $(\sim 1.5 \mathrm{~min})$ with $15 \mathrm{ml}$ distilled water; this step diluted any residual serum containing medium that had been left behind which would, in turn. discourage cell lysis. Cell lysis was accomplished using $\mathrm{H}_{2} 0$ containing $0.2 \mathrm{mM} \mathrm{ZnCl}$ and soybean trypsin inhibitor $\left(1 \mu \mathrm{g} \mathrm{ml}^{-1}\right)$. The $\mathrm{ZnCl}_{2}$ was included to maintain the integrity of nuclei and hormone-containing secretory granules (Hymer and Kuff, 1964; Farrington and Hymer, 1990). Lysis, monitored microscopically, was complete after $\sim 10 \mathrm{~min}$. This diluted lysate was then concentrated to $\sim 3 \mathrm{ml}$ by (1) drawing the lysate out of the CCK into a syringe containing $20 \mathrm{mg}$ DNAse (Type I), solubilized, and then reinjected back into the $C C K$, and (2) then drawn from the $\mathrm{CCK}$ into a concentrating device containing $1 \mathrm{ml}$ of $10 \times$ electrophoresis buffer and consisted of a Spectra pore 7 dialysis membrane 


\section{PART II. PITUITARY CELL ELECTROPHORETIC STUDY}
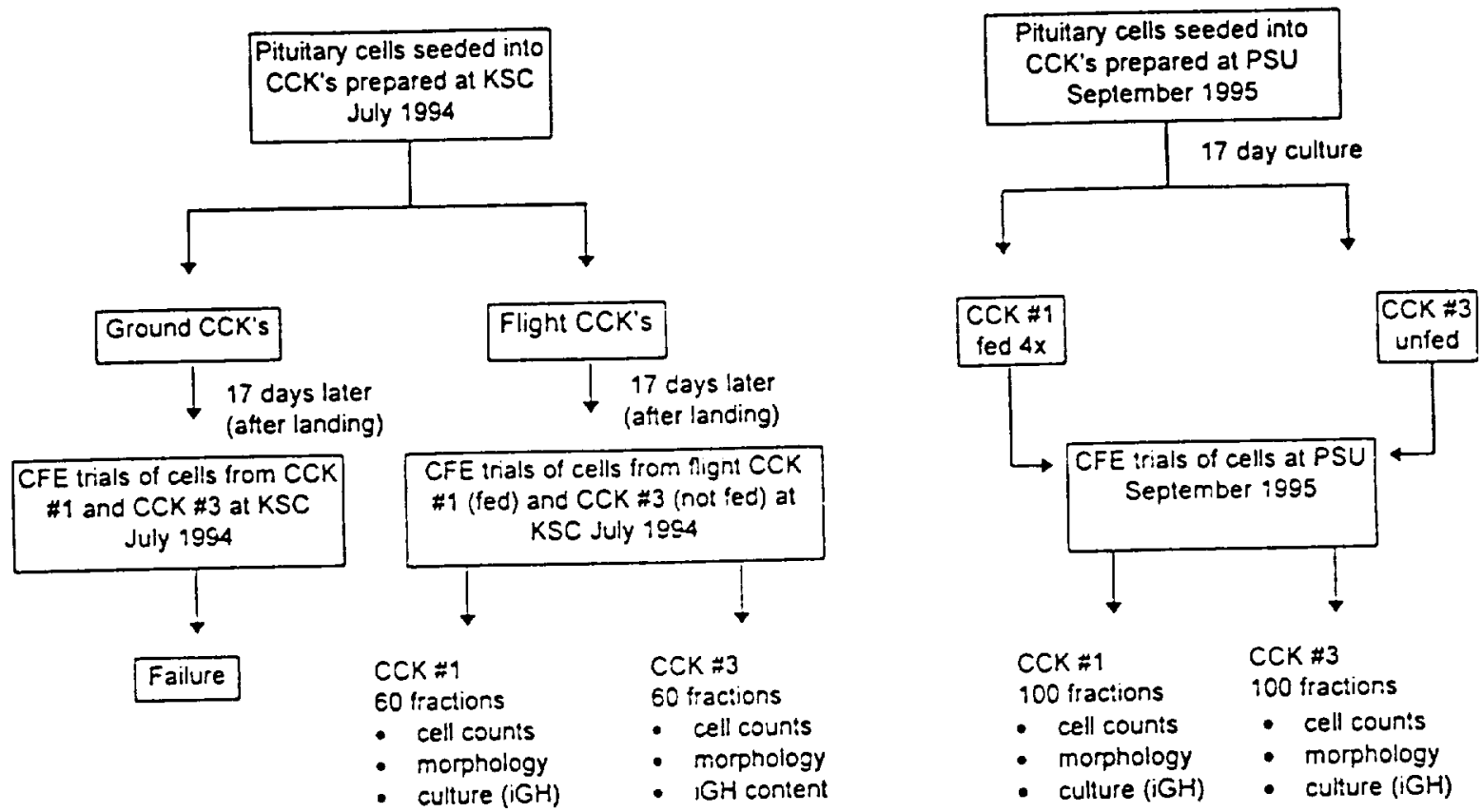

Fig. 2. Experimental design and timing of operations involsing CFE of piruitung cells after microgravity exposure. Cells from flight CCK 1 and CCK $;$ were processed it Kenned Space Center within $S$ h of Shutlle landing using a device lidentified as device $=$ in Table 11 made for this experiment by Misubishi Heary Industries, Lid. This desice malfunctioned after prosessing of cells from both fight CCKs: accordingly, an asychronous ground control experiment was done later using another CFE dorice lidentified as device 1 in Table 1$)$.

(10000 MV) surrounded by polyethylene glycol $60(60000 \mathrm{MW})$.

\section{2. $C F E$}

The carrier buffer consisted of $5 \mathrm{mM}$ HEPES. $30 \mathrm{mM}$ glycine, $0.2 \mathrm{mM}$ potassium acetate, 0.3 $\mathrm{mM} \mathrm{MgCl}, 0.03 \mathrm{mM} \mathrm{CaCl} .220 \mathrm{mM}$ glycerol. $44 \mathrm{mM}$ sucrose, $0.2 \mathrm{mM} \mathrm{ZnCl}_{2}$. Its conductivity and osmolarity were $260 \mu \mathrm{S}$ and $300 \mathrm{mOsm}$. respectively. Results from several preflight CFE trials indicated that this buffer was superior to several others in terms of maintaining cell viability ( $>80 \%$ over 17 days).

Three different CFE devices were used in carrying out this experiment. Two have been described in previous publications (Hymer et al..
1987; Akiba et al., 1995); the third was designed to serve as the ground control unit when synchronous flight and ground processing was done. See Table 1 for operating details and specific sample applications.

\subsection{Post CFE analysis}

Procedures involving cell preparation, $\mathrm{GH}$ immunoassay, HPLC gel filtration and ion-exchange chromatography, immunocytochemistry and cell culture were as described previously (Hymer et al., 1992; Hymer et al., 1996a). Western blotting was done on $5-15 \%$ gradient gels under non-reducing conditions as in previous reports (Farrington and Hymer, 1990). 
Table 1

CFE operating conditions used in this study

\begin{tabular}{|c|c|c|c|c|c|c|c|c|}
\hline Sample & $\begin{array}{l}\text { Sample in space } \\
\text { or ground }\end{array}$ & $\begin{array}{l}\text { Process in space } \\
\text { or ground }\end{array}$ & FFE dericed & Field strength & $\begin{array}{l}\text { Carrier buffer } \\
\text { rate }\end{array}$ & Sample rate & $" / \%$ recovery" & Fig. No. \\
\hline Lysate & Ground & Ground & 2 & $25 \mathrm{~V} \mathrm{~cm}^{-1}$ & $5 \mathrm{ml} \mathrm{min}^{-1}$ & $0.20 \mathrm{ml} \mathrm{h}-1$ & 228 & 4 \\
\hline Ly'sate & Ground & Ground & 2 & $25 \mathrm{~V} \mathrm{\textrm {cm } ^ { - 1 }}$ & $3 \mathrm{ml} \mathrm{min}-1$ & $0.15 \mathrm{ml} \mathrm{h}^{-1}$ & 73 & $\vdots \mathrm{B}$ \\
\hline Lysate & Flight & Flight & 3 & $2 \vdots V \mathrm{~cm}^{-1}$ & $7 \mathrm{ml} \mathrm{min}^{-1}$ & $2.00 \mathrm{ml} \mathrm{h}^{-1}$ & 17 & SA \\
\hline Lisate & Ground & Ground & 1 & $15 \mathrm{~V} \mathrm{~cm}^{-1}$ & $18 \mathrm{ml} \mathrm{min}^{-1}$ & $2.70 \mathrm{ml} \mathrm{h}^{-1}$ & 34 & $\vdots c$ \\
\hline Lisate & Flight & Ground & 1 & $15 \mathrm{~V} \mathrm{~cm}^{-1}$ & $18 \mathrm{ml} \mathrm{min}^{-1}$ & $2.70 \mathrm{ml} \mathrm{h}^{-1}$ & 32 & $\Xi C$ \\
\hline Cells & $\begin{array}{l}\text { Ground (no } \\
\text { media changel }\end{array}$ & Ground & $?$ & $25 \mathrm{~V} \mathrm{~cm}^{-1}$ & $5 \mathrm{ml} \mathrm{min}^{-1}$ & $0.15 \mathrm{ml} \mathrm{h}^{-1}$ & 54 & $S(t o p)$ \\
\hline Cells & $\begin{array}{l}\text { Ground ino } \\
\text { media change) }\end{array}$ & Ground & 2 & $25 \mathrm{~V} \mathrm{~cm}^{-1}$ & $5 \mathrm{ml} \mathrm{min}^{-1}$ & $0.15 \mathrm{mi} \mathrm{h}^{-1}$ & 34 & $S$ (middle) \\
\hline Cells & $\begin{array}{l}\text { Ground (no } \\
\text { media change) }\end{array}$ & Ground & 2 & $25 \mathrm{~V} \mathrm{cm^{-1 }}$ & $5 \mathrm{ml} \mathrm{min}-1$ & $0.15 \mathrm{ml} \mathrm{h}^{-1}$ & $\$ 4$ & Sibontom) \\
\hline Cells & $\begin{array}{l}\text { Flight ( } x \text { me. } \\
\text { did change) }\end{array}$ & Ground & 2 & $25 \mathrm{~V} \mathrm{cm^{-1 }}$ & $3 \mathrm{ml} \mathrm{min}^{-1}$ & $0.15 \mathrm{ml} \mathrm{h}^{-1}$ & 18 & 9.1 \\
\hline Ceils & $\begin{array}{l}\text { Flight (no me- } \\
\text { dia change) }\end{array}$ & Ground & 2 & $=5 \mathrm{v} \mathrm{cm}^{-1}$ & $3 \mathrm{ml} \min ^{-1}$ & $0.15 \mathrm{ml} \mathrm{h}^{-1}$ & 37 & $9 E$ \\
\hline Cells & $\begin{array}{l}\text { Ground (4 } x \\
\text { medial change) }\end{array}$ & Ground & 1 & $15 \mathrm{v} \mathrm{cm}^{-1}$ & $18 \mathrm{ml} \mathrm{min}-1$ & $2.70 \mathrm{ml} \mathrm{h}^{-1}$ & 11 & $9 \mathrm{C}$ \\
\hline Cells & $\begin{array}{l}\text { Ground (no } \\
\text { media change) }\end{array}$ & Ground & 1 & $15 \mathrm{rcm}^{-1}$ & $18 \mathrm{ml} \mathrm{min}^{-1}$ & $2.0 \mathrm{ml} \mathrm{h}^{-1}$ & 16 & $9 \mathrm{H}$ \\
\hline
\end{tabular}

دFFE deice: 1. $1.5 \mathrm{~mm}$ continuous How electrophoresis device $(\mathrm{H} ! \mathrm{mer}$ et al., 198\%: 2. Japanese $1.0 \mathrm{~mm}$ ground free flow electrophoresis unit: 3. Jupanese $4 \mathrm{~mm}$ Highr free flow electrophoresis unit (Akiba et al. 1995). Chamber dimensions: $1.120 \mathrm{~cm} \times$ $8.2 \mathrm{~cm} \times 1.8 \mathrm{~mm}: 2.10 \mathrm{~cm} \times 6 \mathrm{~cm} \times 1 \mathrm{~mm}: 310 \mathrm{~cm} \times 6 \mathrm{~cm} \times 4 \mathrm{~cm}$.

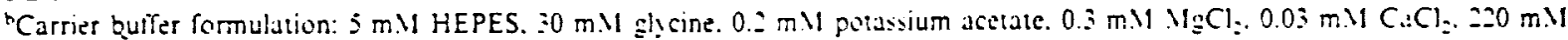
glycerol. If $\mathrm{mMll}$ sucrose. $0.2 \mathrm{mM} \mathrm{ZnCl}$.

"Eithat $\mathrm{GH}$ or total cells.

\section{Results}

The ultrastructure of a rat pituitary cell lysate as well as enzymatically dispersed rat pituitary cells after a 9 day culture is shou'n in Fig. 3. These micrographs represent the type of samples that were used in this microgravity continuous flow electrophoresis (CFE) experiment.

\subsection{Lisate processing (Earth)}

Results of previous studies from our laboratory have shown that $80-90 \%$ of the GH contained in rat pituitary gland homogenates is sedimentable by centrifugation ( $>40000 \times \mathrm{g}$ ), a result which show's that most of the intracellular GH is stored in particle form (Hymer and McShan, 1963; Hayes et al.. 1990). Accordingly we did not attempt to separate free from bound $\mathrm{GH}$ that was contained in each CFE fraction. A typical CFE distribution profile of $\mathrm{GH}$ particles contained in a freshly prepared lysate from an 8-day pituitary cell culture show's a dominant anodal $G H$ peak: a small cathodal $G H$ peak and immunopositive material which did not migrate in the field (Fig. 4). This pattern is similar to others using freshly prepared rat anterior pituitary homogenates (Hayes et al., 1990).

\subsection{Lysate processing (microgratity)}

A concentrated pituitary cell lysate was prepared in space from unfed cells on mission day 9 following the procedure described. CFE processing of this lysate was done according to the experimental design shown in Fig. 1. The concentration of $\mathrm{GH}$ in the flight lysate was $\sim 20 \%$ greater than that in the synchronous ground control preparation (see Fig. 5A. Fig. 5B), a result which is entirely consistent with the finding that there were greater amounts of $\mathrm{GH}$ released into the 9-day culture medium prior to lysate prepara- 
tion (Hymer el al. 1996(1) (Fig. +B). Only onehalf of the 5n total outlet ports were actually awailable for sumple recovery during microgravity processing: therefore onl. $\mathrm{GH}$ concentrations in those 30 iractions are shown in Fig. 5A. After CFE processing in microgravity. 9 of 30 fractions contained detectitble $\mathrm{GH}$ : after synchronous ground processing. only 5 of 60 fractions conlained detectuble GH (Fig. SA is. Fig. SB). Three $\mathrm{GH}$ peaks "ere found after flight processing. but

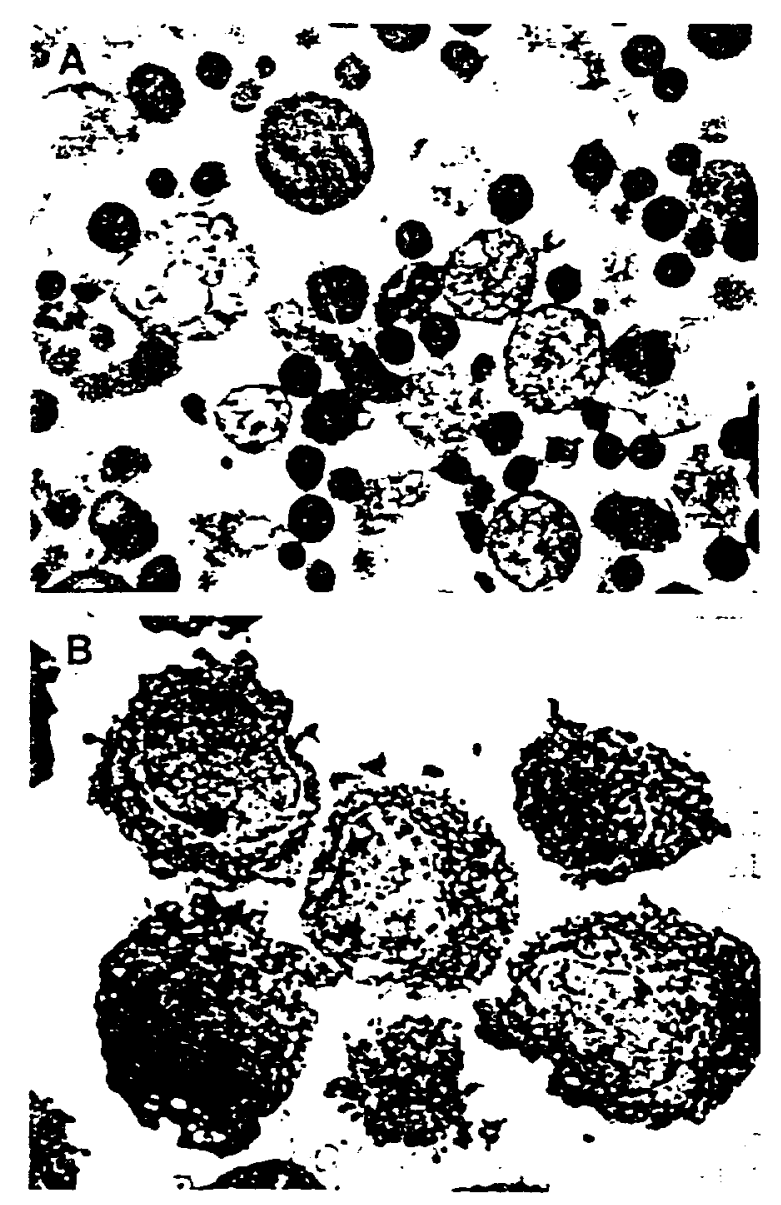

Fig. 3. Elecirsn micrographs of a rat anterior pituitary cell lysate (tofl and enzymatically dispersed rat pituitary cells that had been in euiture for 9 days (bottom). The culture medium was identicul to that used in microgravity (Hymer et al., $1996 a$ ) and was not changed during the 9 days. Hormone containing secretory granules are prominent. These sampies are representative of the types of samples that were subjected to CFE in micresravity (lysate) or after microgravity exposure (cells).

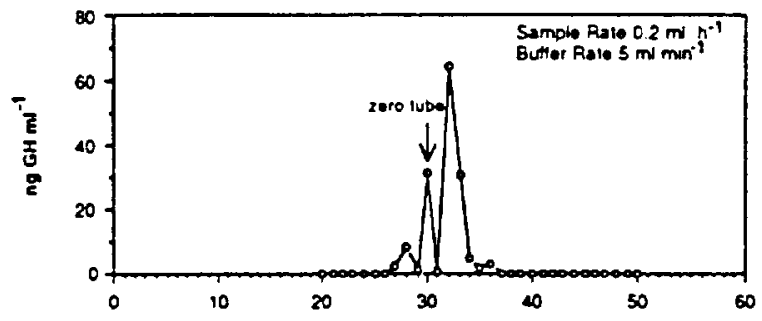

Fig. 4. Representative ground-based CFE distribution profile of $\mathrm{GH}$ particies prepared from rat pituitary cells in culture (CCK) for 8 days prior 10 lysis and CFE. See also Tuble 1. The zero tube identified in this and subsequent figures repre. sents the elution position of the material when no electric field is applied.

only one was present in the ground trial. When frozen aliquots of these same concentrated lysates were subsequently processed on earth. the distri-

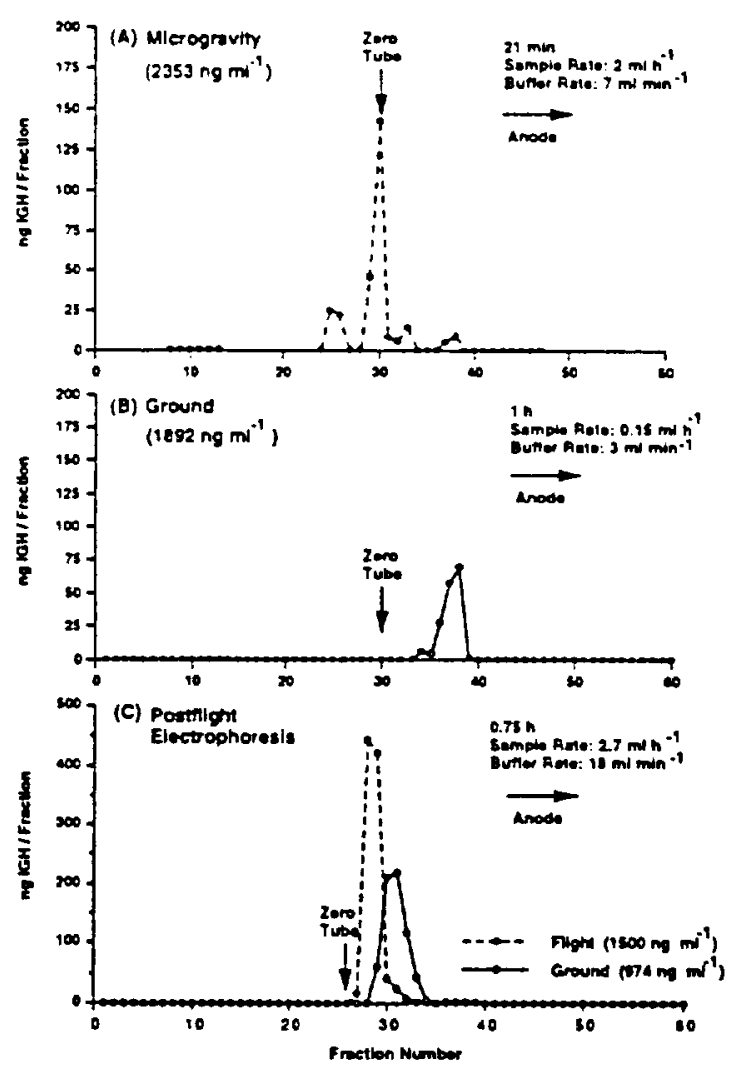

Fig. 5. Mobility profiles of GH-containing material in lysate after CFE processing in microgravity (A) or on earth (B). As shown in Fig. 1, some of the initial sample from $A$ and $B$ was frozen and later electrophoresed (C) (see Table 1). 
bution profiles of $\mathrm{GH}$ were essentially identical (Fig. 5C).

In order to determine if there were any differences in apparent molecular weight of $\mathrm{GH}$ variants that might be present in these fractions, Western blots were prepared on those fractions containing sufficient $\mathrm{GH}$. The complex profile of GH variants that emerges when SDS-PAGE is used under non-reducing conditions is reasonably well documented (Lewis, 1992); their complexity from both the ground and flight CFE fractions is therefore not unexpected. Densitometry of these blots revealed that there were some differences in $\mathrm{GH}$ rariants between these fractions: those from flight were the most obvious (Fig. 6. shaded areas). These differences were in $\mathrm{GH}$ molecular weight regions (based on the mobilities of prestained molecular weight protein standards) identified at the top of Fig. 6.

Small $(0.1 \mathrm{ml})$ aliquots of these lysate fractions obtained after CFE were also fractionated by HPLC gel filtration or anion-exchange chromatography to obtain information concerning separation of general pituitary protein. Shown in Fig. 7 are the OD 280 gel filiration profiles of $\mathrm{pH}$ 10 solubilized material that was contained in (1) the original lysates before CFE (Fig. 7.A: molecular weight standards are shown in insert): (2) fractions 36 and 37 (which make up $51 \%$ of the GH peak) after CFE processing of the synchronous ground control lysate (Fig. $i B$ ) and (3) the fractions making up low mobility (fractions $8-12$ ) and higher mobility (fractions 37-38) protein after CFE processing in microgravity (Fig. 7C). While the general protein profiles of the starting lysates were similar, there was a tendency for the flight samples to contain more high molecular weight material ( $>\sim 29000$ ) (Fig. 7A). Differences in OD 280 patterns between fractions from the ground lysates and flight lysates were relatively minor. The reason(s) for the absence of $\mathrm{OD} 250$ material in CFE fractions eluting between 15 and $35 \mathrm{~min}$, material that was present in the starting preparation, is unknown; it may reflect differential susceptibility to proteolysis.

Because anion-exchange chromatography of cell culture media collected from fed cells in this experiment had shown some interesting results

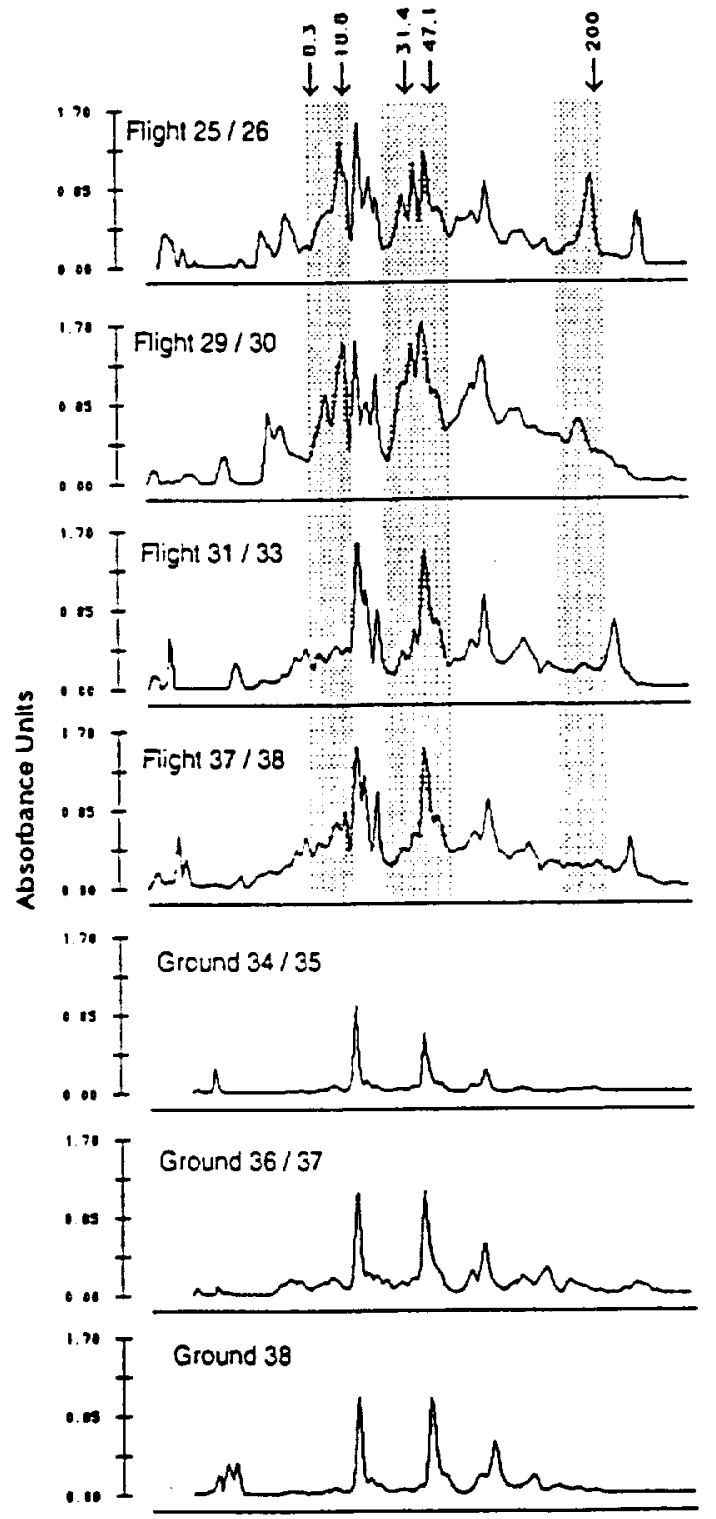

Fig. 6. Optical density tracings of $\mathrm{GH}$ Western blots of samples shoun in Fig. S. Highest molecular weight material is at far right. Shaded areas show positions where changes in $\mathrm{GH}$ forms in the different CFE fractions from the flight trial are most apparent. Molecular weight markers are identified at the top.

(Hymer et al.. 1996a; Fig. 9), we also fractionated the CFE lysate material from the CFE flight fractions containing $\mathrm{GH}$ by anion exchange HPLC. Only very small amounts of flight material 
were processed due to insufficient sample volume. The general OD 280 profile of the proteins from

A.

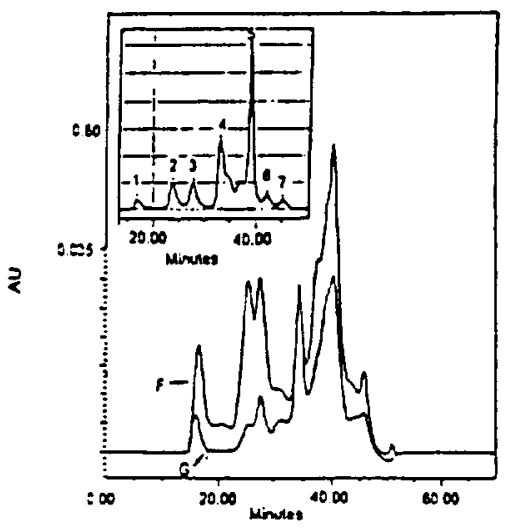

B.

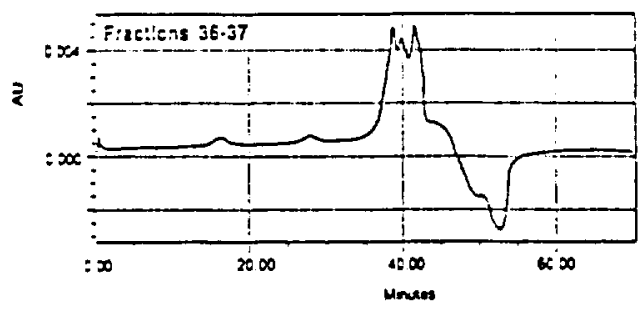

C.
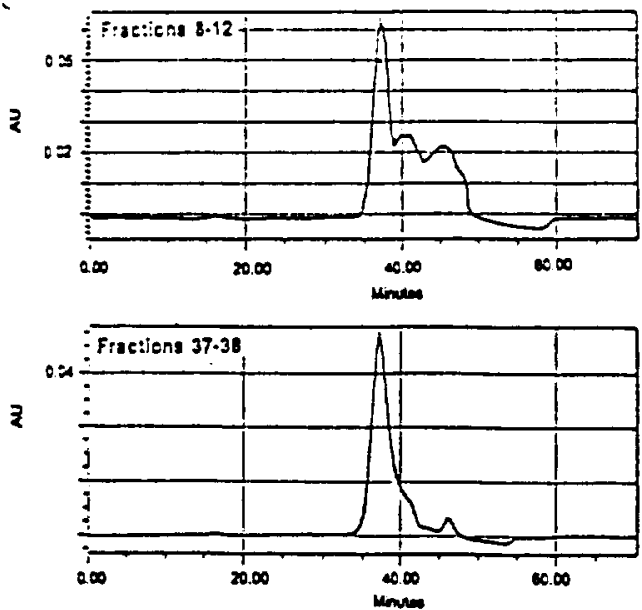

Fig. 7. Gel filiration profiles (OD 280 ) of $\mathrm{pH} 10$ solubilized material that was contained in $(A)$ the original lysate before CFE (B) fructions $36-37$ which make up $51 \%$ of the GH after CFE processing on earth or (C) in the least and most mobile fractions after processing in microgravity. Protein standards, identified in insert to panel $A$, were: (1) blue dextran, $2 \times 10^{6}$; (2) $\beta$-amplase. $2 \times 10^{5}$; (3) BSA, $66 \times 10^{3} ;$ (A) carbonic anhydrase. $29 \times 10^{3}:(5)$ ribonuclease, $13.6 \times 10^{3}:(6)$ aprotinin. $6.5 \times 10^{3} ;(7)$ vasopressin, $1 \times 10^{3}$. the intracellular lysate (fractions 25-37: Fig. 5A) was similar to those proteins contained in the culture medium (Fig. 9; Hymer et al., 1996a) in that a large protein peak eluted from the column $\sim 2 \mathrm{~min}$ before the salt gradient began, followed by a series of major protein peaks eluting between 15 and $20 \mathrm{~min}$. Minor differences in the OD 280 patterns in these regions indicated that some protein separation was occurring during CFE processing in microgravity (not shown).

\subsection{Coll processing (Earth)}

The electrophoretic mobility profiles of unfed primary rat anterior pituitary cells that had been in culture for 8 days are shown in Fig. 8 (three experiments). These trials were designed to mimic the cell processing trial that had been originally planned on day $\&$ for the $1.11 \mathrm{~L}-2$ experiments. They show considerable variability. The cariability could be due to minor differences in trypsinization methodology between experiments or differential sensitivity of the individual cell preparations to the lack of media changes re. quired by the design of the flight experiment. However. it seems clear from these preflight trials that a majority of the cultured cells exhibit anodal mobility under these conditions of electrophoresis (Fig. 8. bottom panel), a pattern similar to those seen in previous studies (Hymer et al.. 1987).

\subsection{Cell processing (microgratiny)}

Due to the technical problems with the flight electrophoresis hardware (Kobayashi et al.. 1996). it was not possible to carry out the cell electrophoresis trial as planned and the single microgravity CFE trial that was done (as planned) used pituitary cell lysate (Fig. 5). This made two cell culture kits available after Shuttle landing; we therefore tested the effect of microgravity exposure on the electrophoretic mobility of cells that had been in the culture for 17 days. In one case (CCK 1) the cells had been fed four times, in the other (CCK 3) the cells were kept in their original seeding medium. A detailed morphological description of the cells in these two CCKs is given in the companion report (Hymer et al., 1996a). The 

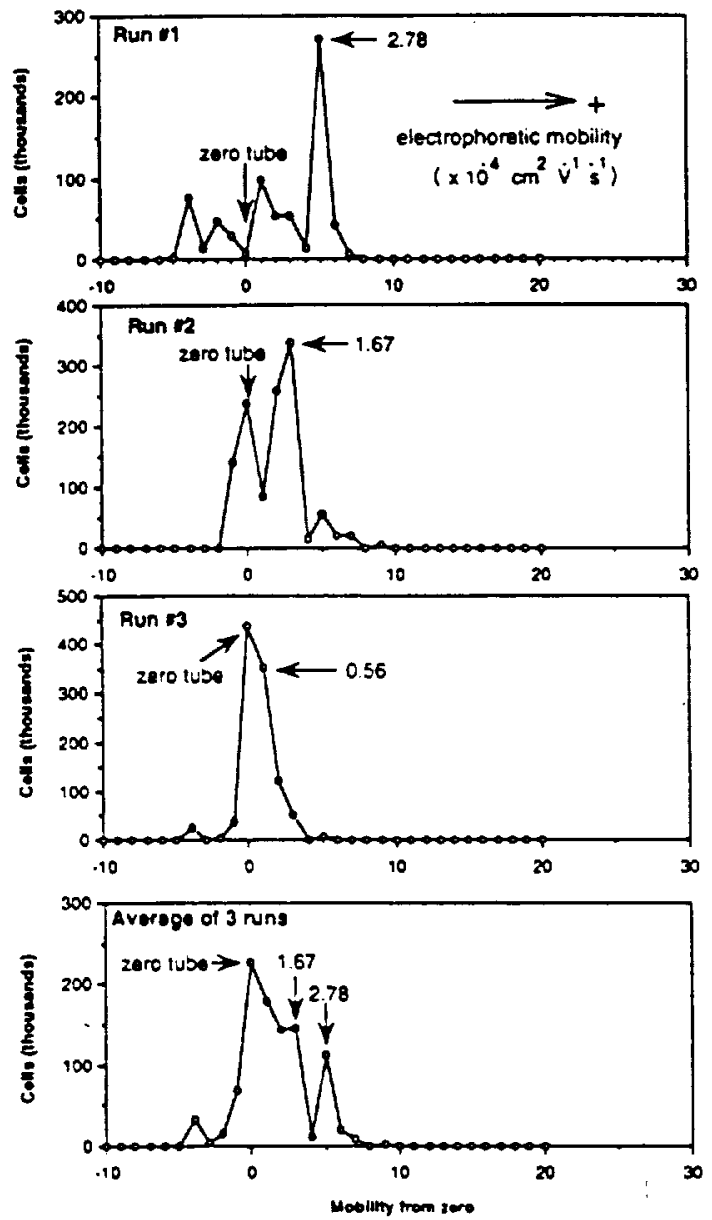

Fig. 8. Electrophoretic mobility profiles of unfed rat anterior pituitary cells that had been in culture for 8 days. $(n=3$ experiments: the average is shown in the bottom panel). Actual electrophoretic mobility units of cell peaks, expressed as $10^{-1}$ $\mathrm{cm}^{2} \mathrm{~V}^{-1} \mathrm{~s}^{-1}$, are identifed in this and the next figure.

mobility profiles of cells trypsinized from these two CCKs and electrophoresed within $8 \mathrm{~h}$ of Shuttle landing showed that fed cells had greater anodal mobility than unfed cells (compare Fig. 9A and Fig. 9E). This was not true when asynchronous ground control cells, cultured for 17 days, were electrophoresed (Fig. 9C vs. Fig. 9G).

Cells from flight and ground CCK 1 , after CFE, were cultured for 6 days to determine if the separated cells released $\mathrm{GH}$ and if the CFE process enriched GH-producing cells. The data in Fig. 9B and Fig. 9D establish (1) that micrograv- ity-exposed fed cells released $\sim 5 \times$ more hormone postflight than corresponding ground controls (reason unknown), (2) that hormone-producing cells exposed to space showed greater bandspread than the corresponding ground controls and (3) that high producer cells after spaceflight tended to be among the most mobile (e.g. those in fractions $14-18$ ).

Because cells were limiting from flight CCK 3 (see Materials and Methods). post CFE culture was not done. However, their intracellular $\mathrm{GH}$ concentrations mirrored the general cell profile, a result that was generally similar to the ground sample (Fig. 9F vs. Fig. 9H). It is important to indicate that the average electrophoretic mobility distribution profiles of unfed cells in the preflight irials (Fig. 8, bottom panel) and those from unfed flight cells (Fig. 9E) are similar. These profiles add support to the concept that there may be specific microgravity-feeding interactions which affect cell electrophoretic mobility.

\section{Discussion}

The original objective of this experiment was to determine if microgravity exposure affected the electrophoretic mobility of either cultured rat pituitary $\mathrm{GH}$ cells or intracellular GH-containing particles. Our previous experiments which documented microgravity specific changes in $\mathrm{GH}$ cells from either spaceflow'n rats (Grindeland et al., 1987; Hymer et al. 1992) or spaceflown cells themselves (Hymer et al., 1996a.b.c) established the underlying rationale for this objective; i.e. that CFE technology might aid in helping to define mechanisms of gravisensing in the $\mathrm{GH}$ cell. Additional secondary objectives emerged automatically, i.e. (1) demonstration of CFE processing advantages in microgravity and (2) demonstration of ancillary methods required for these CFE operations (e.g. preparation of fresh solutions. trypsinization, cell lysis).

Even though three different CFE devices were used in this experiment, all utilize essentially the same technology, i.e. separation in rectangular chambers using the same low ionic strength buffer. As shown in Table 1, cell recoveries aver- 

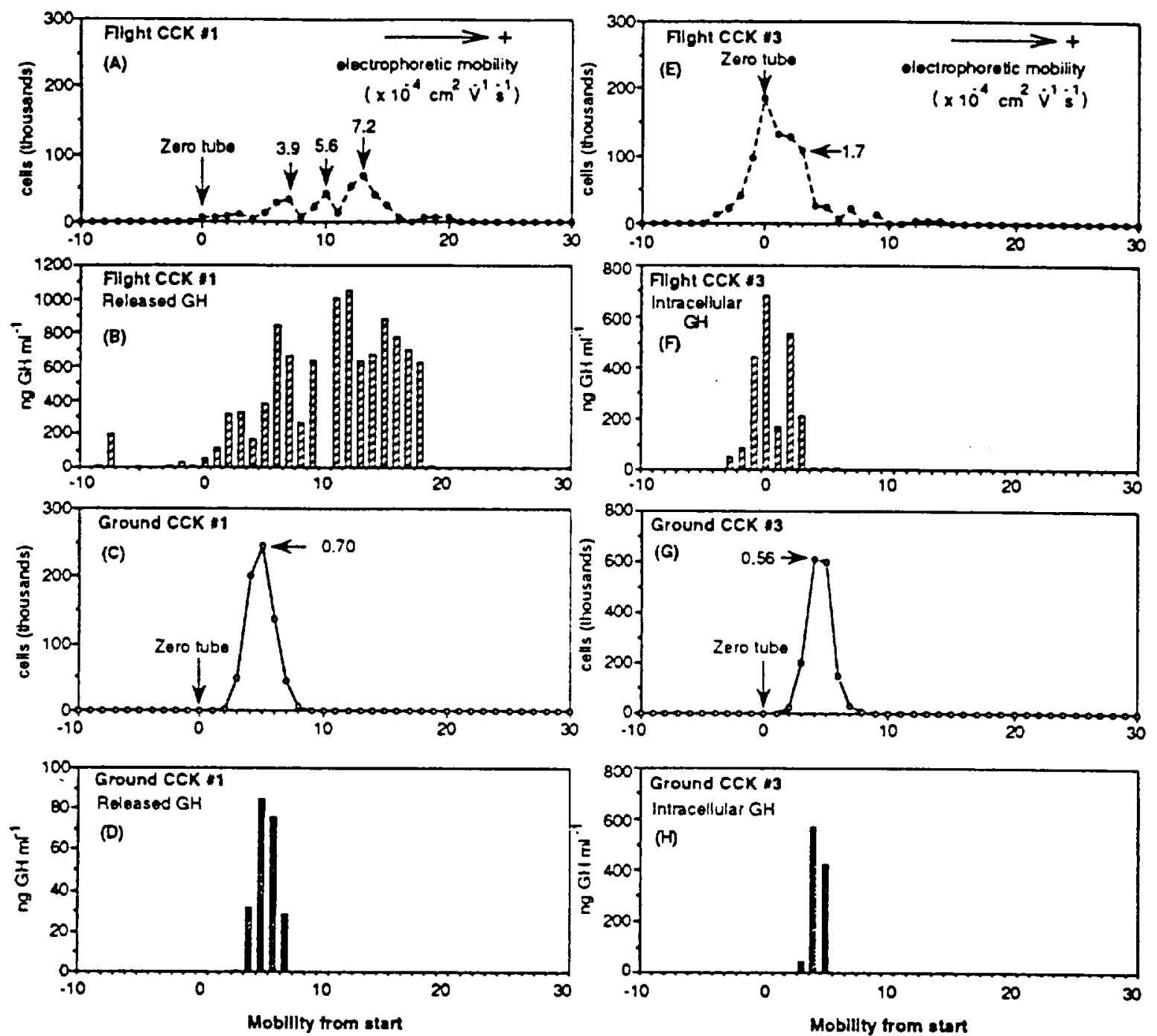

Fig. 9. Cell mobility profiles after inpsinization from flight and ground CCKs are shoun in panels (A), (C), (E) and (G). CCK I celis fed $4 \times$; CCK 3 cells not fed (see Fig. 2 and Table 1 for details). GH released from cells in CCK 1 after CFE and a 6-day postfight culture: flight (panel B), ground (panel D). Intracellular GH contained in different CFE fractions prepared from celis originally contained in CCK 3; flight (panel F), ground (panel H).

aged $29 \%$ although there was considerable variability. This average compares favorably with that reported for a previous space CFE experiment using rat pituitary cells (20\%, Hymer et al., 1987). The low recovery from the flight lysate trial may be due to the fact that only one-half of the fractions were collected and many had low volumes.

Even though all of the original objectives of this experiment could not be met, new results were obtained. For example, evidence for a CFE processing advantage in microgravity is indicated by (1) increased throughput (the flight sample was $5.6 \times$ more concentrated than the ground); (2) greater bandspread of $\mathrm{GH}$ containing particles in the lysate sample (Fig. 5) and (3) better discrimination of some $G H$ variants within different CFE fractions (Fig. 6). Since this same microgravity 
sample did not show a mobility difference $u$ hen it was processed at earth gravity (Fig. 5), we conclude that microgravity exposure has little effect on the net surface charge of intracellular GH-containing particles contained in lysates.

The idea that microgravity may effect net cell surface charge density, depending upon the cell culture conditions (Fig. 9), is to our knowledge entirely new. We are aware that the collection and interpretation of electrophoretic data is a nontrivial exercise. The technique requires very careful control if artifacts are to be avoided. The approaches which minimize these problems in electrophoretic studies have been critically reviewed by Seaman (Seaman. 1975). For example the use of low ionic strength buffers encourages the adsorption of cellular leakage products from cells. as well as enzymes on other macromolecules in the suspending medium. at the cell surface. The electrokinetic stability (Seaman, 1975) of mammalian cell surfaces is also diminished in the low ionic strength media normally used in CFE devices. Nevertheless. the fact that cells from flight CCK 1 and 3 had such very different elec. trophoretic mobilities in sequential CFE postflight processing trials strongly supports underlying physiological. rather than artificial. causative factor(s).

Our companion report showed that the frequency of cell feeding in low gravity affected the cell morphology as well as the quantity and quality of certain hormones (Hymer et al., 1996a). We speculate that the greater mobility of the fed cells may reflect more hormone on their surfaces resulting from increased local concentration gradients caused by lack of microconvection in microgravity. The early report of St. John (St. John, 1986) which established the presence of hormone on the surface of rat pituitary cells supports the basic mechanism underlying this idea. Cell surface hormone could result from the exocytosis process; its implication for cell function is unknown. We have speculated that cell surface hormone could be recycled back to the golgi zone (together with secretory granule membrane) to provide a seed site for the formation of a new granule (Hymer et al., 1992). However, most proteins. glycoproteins, and lipoproteins at the cell surface will lack sufficient net charge densities to produce electrophoretic mobilities in excess of $3.5 \times 10^{-4} \mathrm{~cm}^{2} \mathrm{~V}^{-1} \mathrm{~s}^{-1}$. Only nucleic acids have the intrinsic capability to produce the very high cell electrophoretic mobilities of the fed, microgravity-exposed cells (Fig. 9). Thus. a partial explanation for the different electrophoretic behavior of these cells may lie in the presence of adsorbed DNA or R.NA. Why the combination of feeding and microgravity would promote a high concentration of cell surface nucleic acid is unknown.

Bauer, in his discussion concerning the signifcance of cell electrophoretic mobility (Bauer. 1994 b), raises a number of points that are relevant to our current data set. He points out that most mammalian cells have a narrow mobility range (0.5-3.5 $\times 10^{-+} \mathrm{cm}^{2} \mathrm{~V}^{-1} \mathrm{~s}^{-1}$ ) even though several different iypes of electrophoresis derices have been used under very different conditions of analysis. Bauer also reviews the literature which attempts to relate the electrophoretic mobility value of the cell to its functional state. He concludes that electrophoretic cell mobility may relate to (1) the state of cell differentiation (but not strictly so). (2) "switching" as the cell changes from one physiological state to another or (3) ligand binding to its receptor (e.g. such as in the case when a monokine binds 10 a lymphocyte subclass). The electrophoretic values of cells processed by CFE in this study are identified in Figs. 8 and 9. Note that for all trials. except the one using cells from flight CCK 1 , the EPMs are within the range identified by Bauer. However, a majority of the cells which had been fed in microgravity had mobilities $>3.5 \times 10^{-4} \mathrm{~cm}^{2} \mathrm{~V}^{-1}$ $\mathrm{s}^{-1}$, e.g. cell peaks with EPMs of 5.6 and $7.2 \times$ $10^{-4} \mathrm{~cm}^{2} \mathrm{~V}^{-1} \mathrm{~s}^{-1}$ as identified in Fig. 9. Because high mobility cell populations were not found in flight CCK 3, the data support the idea that feeding pituitary cells in microgravity alters their net surface charge. Whether this reflects a gravisensing mechanism, or is the result of one, is unknown.

How might our new microgravity data relate to our previous spaceflight experiment (Hymer et al., 1987) and those of others that have been reviewed by Bauer (Bauer, 1994b)? First, an earlier 1983 
study from our laboratory showed that GH cells could be enriched by either density gradient electrophoresis or continuous flow electrophoresis. even though measurements of cell mobilities by two analytical methods (microscopic electrophoresis and laser tracking electrophoresis) revealed little difference between unpurified rat anterior pituitary cell suspensions and $G H$ cell enriched suspensions (Plank et al.. 1983). At that time we suggested that a microgravity experiment could help to establish whether or not the higher mobility of $G H$ cells seen in ground-based CFE was truly atributable to a difference in their net surface charge or merely attributable to an artifact caused by fallback in one of the $\mathrm{GH}$ cell subpopulations having high density $(p>1.071 \mathrm{~g}$ $\mathrm{cm}^{-5}$. In fact. evidence for the former explanation was obtained in a 1983 spacefight experiment which showed that anodal regions of the cell distribution profile contained more $G H$ per cell and that there were $3 \times$ more GH cells in these fractions than in those of the slowest moving cells (Hymer et al.. 1987). It is important to note that this earlier microgravity experiment was done by placing freshly prepared cells into a sealed conical tube at Cape Kennedy prior to launch. These cells were kept in a triethanolamine based buffer, low ionic strength buffer until the time of CFE processing in microgravity; only after collection were they exposed to buffers that were more physiologically compatible. Obviously the cell processing envionment in our most recent IML-? experiment was much more physiologically favorable. i.e. cells were maintained in a serum-bicarbonate containing Hepes buffered medium (Hymer et al., 1996a) for their entire microgravity exposure before CFE processing and culture at KSC. The data in Fig. 9 not only establish that high mobility $\mathrm{GH}$ producing cells were recovered from flight (but not ground) CCK 1, but also that a microgravity-feeding interactive effect occurred which apparently affects not only hormone output but cell surface charge as well.

What set of conditions might result in microgravity;feeding hormone release/net surface charge changes of the type seen in this IML-2 experiment? In the companion report we speculated that autocrine paracrine interactions play a large role in pituitary cell gravisensing (Hymer et al.. 1996a). We suggest that the microgravity-specific cell feeding interactions in the FSH ACTH cells found in the cell culture portion of this IML-2 experiment might affect the electrophoretic mobility profile of a $\mathrm{GH}$ cell subpopulation by exposing these cells to a different hormonal environment.

What consequence. if any. a change in cell surface charge might have on the quantity or quality of different hormones released from the pituitary gland of the intact organism obviously: requires further study. Nevertheless. this IML-2 experiment showed that the rat pituitary cell $5: 5$ tem lends itself well to microgravity experimentation involving the coupled technologies of cell culture and continuous flow electrophoresis.

\section{Acknowledgements}

This study was supported by NAS.t grant $\therefore A G 8-953$. The lysate CFE trial was done by Dr. Leroy Chiao and Dr. Donald A. Thomas. $\mathrm{Ve}$ acknowledge the superb and often heroic wcrk done by the entire payload specialist crew of STS. 65 in making this electrophoresis experiment happen.

\section{References}

Akiba et al. (1995) Separation of bucterial cells by free fiow eiectrophoresis under microgravity: a result of the Spacelab-Japan project on space shuttle flight STS-47. Aitu Astronautica $36(3), 177-181$.

Barrelier, V.. Watzke. E. and Gibian. H. (1958) Einfache apparatur für die trägerfreie präparative durchlauf-elektrophorese. Z. Naturforsch. 13B, 754.

Bauer. J. (1994a) Cell Electrophoresis. CRC Press. Inc.. Boca Raion. FL.

Bauer. J. (1994b) The negative surface charge density of cells and their actual state of differentiation or activation. In: Bauer, J. (Ed), Cell Electrophoresis, CRC Press, Inc., Bocs Raton, FL.. pp. 267-280.

Dalens, F., Roux-de Balmann, H. and Sanchez, V. (199\$) Improved operating conditions for preparative separation of proteins by continuous flow zone electrophoresis. Bioseparation 5, 127-139.

Farrington, M. and Hymer. W. (1990) Growth hormone aggregates in the rat adenohypophysis. Endocrinology 126. $1630-1638$. 
Grindelund. R.. Hymer. W. Furrington. M., Fast. T.. Hayes, C., Motter, K., Patil. L. and Vasques, M. (1987) Changes in pituitary growith hormone cells prepared from rats flown on Spacelab 3. Am. J. Physiol. 252, 209-215.

Hannig. K. (1961) Die irägerfreie koninuierliche elektrophorese und ihre ankendung. Anal. Chem. 181, 244.

Hunnig. K.. Kowalski. M.. Klöck. G.. Zimmerman. U. and Mang. V. (1990) Free-flow electrophoresis under microgravity: Evidence for enhanced resolution of cell separation. Electrophoresis 11, 600-604.

Hayes. D.. Exion. C.. Salada. T.. Shellenberger. K.. Waddle. J. and Hymer. W. (1990) Separation of rat pituitary secretory granules by continusus fow electrophoresis. Electrophoresis $11.9-6-9-8$.

Hymer, W. and Hatfield. J. 1983) Purification of cells from the anterior pituitary. In: Colouick and Kaplan (Eds.). Methods in Enzymology. Acadermic Press. pp. :\$7-287.

Himer. W. and Kuff. E. (1964) Isolation of nuclei from mummalian tissues ihrough the use of Triton $\times-100$. J. Histochem. Cytochem. 12. 359-363.

Himer. W. and McShan. W' (1963) Isolation of rat fituitar. granules and the study of their biochemical properties and hormanal ictivities. J. Cell Biol. 17,6i-\$6.

Hymer. W. Barlow. G.. Blaisdell. S.. Cleveland. C.. Farrington. H.. Feidmeier. M. Grindeland. R.. Hatield. J.. Lanham. J.. Lewis. M.. Morrison. D.. Oluck. B.. Richman. D. Rose. J.. Sitharp. D.. Sn!der. R.. Swanson. C.. Todd. P. and Iilinger. W. 1198; Continuous fow electrophoresis sepuration of proteins and cells from mammalian tissues. Cell Biephys. 10.61-\$5.

Hymer. W.. Grindeland. R.. Krasnov. I., Victorov. I.. Motler. K.. Mukherjee. P.. Shellenberger. K. and Vasques. M. (1992) Efrects of spaceficht on rut pituitary cell function. J. Appl. Physiol. 7312). 151S-157S.

Hymer. W.. Grindeland. R., Salada. T., Cenci. R.. Krishnan. K.. Nukai. C. and Naguoka. S. (1996a) Feeding frequency alfects cultured rat pituitary cells in low gravity. J. Biotechnol. 47. 289-312.

Hymer. W., Grindeland. R., Salada. T., Nye. P., Grossman, E. and Lane. P. (1996b) Experimental modification of rat pituitary grow'th hormone cell function during and after spaceflight. J. Appl. Physiol. 80(3). 955-970.

Hymer. W.. Salada. T., Avery. L. and Grindeland. R. (1996c) Experimental modification of rat pituitary prolactin cell function during and after spaceflight. J. Appl. Physiol. in press.

Kessler. J. and Bier. M. (1977) Prog. Astron. Aeron. 52 , $125-149$.

Kobayushi et al. (1996) Secretory component. the receptor for polymeric immunoglobulin. has nothing to do with $\beta$ galactosyltransferase in human milk. Immunol. Lett. 50. 99-104.

Lewis. L. (1992) Growth Hormone: What is it and what does it do. Trends Endocrinol. Metab. 3. 117-121.

Morrison. D. (1994) Cell electrophoresis in microgravity: past and future. In: Bauer. J. (Ed.). Cell Electrophoresis. CRC Press. Inc. Boca Raton. FL. pp. 283-\$13.

Plank. L., Hymer. W.. Kunze. E.. Marks. G.. Lanhum. J. and Todd. P. (1983) A study of cell electrophoresis as a means of purifying growth hormone secieting cells. J. Biochem. Bicphys. Methods 8. 275-2S9.

Rhodes. P.. Snyder. R. and Roberts. G. (19\$9) Electrod namic distortion of sample strcums in continuous flow elec. trophoresis. J. Coll. Interface Sci. 129, -8-90.

Roman. M. and Brown. P. (1994) Free-fiow electrophoresis. Anal. Chem. 66(2). S6t-9+A.

Seaman. G.Y.F. (1975) Electrokinetic behavior of red cells. In: D. Maci. Surgenor (Ed.). The Red Blood Cell. Vol. 2. Ind Ed. Academic Press. New York. pp. $1135-1229$.

St. John. P. (1986) Anti-proluctin cell-surface immunoreactivity identifies a subpopulation of lactotrophs from the rat anterior pituitary. Endocrinology 119(6), 2753-2795. 